\title{
The Implementation of CIA (Creative, Innovative and Active) Learning Approach as a Solution for the Monotonous of Online Learning System in the Covid-19 Pandemic Era
}

\author{
Fentry Hernaningi Ruing ${ }^{1}$, Mardiani ${ }^{2}$ \\ Universitas Sawerigading Makassar, Indonesia ${ }^{1,2}$ \\ \{fentryruingunsa@gmail.com $\left.{ }^{1}\right\}$
}

\begin{abstract}
When COVID 19 attacked, the decision made by the government was to impose an online learning system. Unfortunately, various problems arose that required universities to take responsive steps to find the solutions to the monotonous of the online learning system which made students' enthusiasm for online lectures drop dramatically due to the ability of lecturers in utilizing online applications which was limited on giving face-to-face lectures virtually without any modification. This study aimed to elaborate the effectiveness of applying CIA learning approach as an effort to increase students' enthusiasm and interest in the midst of the monotonous of face-to-face lectures virtually during the Covid-19 pandemic. The researcher used descriptive qualitative research methods. The samples used were 100 students from various disciplines at Sawerigading University, Makassar who were chosen randomly. The data collection technique was through questionnaire and observation. In general. The results showed that students' interest in online learning systems increased from $12.7 \%$ which stated that the learning system applied by lecturers during the first period of the pandemic was less qualified to $61.8 \%$ of high quality in the second period so that the students felt very interested in joining the online system. The students response agreed that the online learning system by Sawerigading University lecturers was more creative, interactive and active after the CIA learning approach was applied through various activities in the virtual room. These results identified that the students gave positive responses to the application of the CIA learning approach as an effort by the University of Sawerigading Makassar to find a solution to the problem of low student enthusiasm for face-to-face lecture methods online in a virtual room that previously seemed monotonous and less attractive.
\end{abstract}

Keywords: CIA Learning Approach; Online; Monotonous

\section{Introduction}

The first quarter of 2020 was the most difficult time experienced by people from all over the world when the Covid -19 virus attacks all countries over the world and paralyzed various 
sectors. Indonesia itself, received the impact of Covid -19 so that various sectors experienced suspended with the implementation of the PSBB (Large-Scale Social Restrictions). The only sector that continues to move is the health sector, which from the beginning, the middle to the end, will always be at the forefront in Indonesia. Then what about the education sector, especially universities?

Based on the circular of the Ministry of Education and Culture (Kemendikbud) Number 15 of 2020 concerning Guidelines for Organizing Learning from Home in the Emergency of the Spread of Covid-19 [1], as well as the previous circular, the Circular of the Minister of Education and Culture Number 4 of 2020 concerning the Implementation of Education in Emergency Times Coronavirus Disease (Covid -19) explained that the purpose of transferring the face-to-face learning system to an online learning system is so that the rights of each student to continue to receive educational services can be fulfilled even in difficult pandemic times. In addition, the implementation of the online learning system is none other than to protect students from the spread of the COVID 19 virus as well as break the chain of its spread [2].

Online learning is learning that is able to bring together the students and lecturers to carry out learning interactions with the help of the internet [3]-[4] argues that there are several elements to support the implementation of an online learning system, namely smartphones, laptops, computers, tablets, and iPhones as well as a stable internet network that can be used to access information anytime and anywhere. During this PSBB period, various universities in Indonesia are required to be able to carry out strengthening learning online [5]. In some developed countries, learning online has become a demand for education since the last few years [6], however, for developing countries like Indonesia, the online learning system is still a transition from blended learning to online learning.

With the issuance of the circular (Kemendikbud) Number 15 of 2020, various parties who are struggling in education, without exception, take quick steps to respond to the circular and require all related elements, especially lecturers and students to interact with technology, various kinds applications, as well as virtually communication. This fast-paced change with very minimal preparation made the adaptation process from face-to-face offline to online encountering various obstacles. Some of the impacts of the application of the online learning system on students are (1) online learning still confuses students (2) students become passive, less creative and productive, (3) the accumulation of information / concepts on students is less useful, (4) students experience stress, ( 5) increase students' language literacy skills [7].

One of the crucial problems that Sawerigading college then faced during the Covid 19 pandemic was the monotonous of the online learning system implemented by the lecturers. This situation causes the enthusiasm of students to take courses online drop dramatically. Based on the results of a survey conducted by the Sawerigading University Quality Control in order to measure the effectiveness of the online learning system by lecturers at Sawerigading University Makassar, it was found that $69 \%$ of the total 100 students stated that they were not at all interested in the monotonous online learning system. This is caused by the online system learning model used by lecturers at Sawerigading University Makassar during the period from May to July 2020 was a virtual face-to-face method. As many as $68 \%$ of students responded that the online system learning model used by lecturers at Sawerigading University in Makassar was of poor quality because it was monotonous where the lecturer became the speaker center so that students only became the listeners. The result was that students replace their screens with virtual backgrounds so that they could do other activities and did not focus their attention on the lecturers' explanations. 
Facing the results of the survey, the university under the command of the University's Quality Control (LPM) was actively making various efforts to maintain the quality of education at Sawerigading University Makassar in the midst of the difficult period of the Covid 19 pandemic regularly and continuously regarding the maximum use of online applications through the application of the CIA learning model (CREATIVE, INNOVATIVE, and ACTIVE) as an effort to increase student enthusiasm and interest in the midst of the monotony of face-to-face lectures virtually during the Covid -19 pandemic.

In the application of the CIA learning model, lecturers used an integrated learning strategy using strategies, methods, approaches and teaching techniques both learning procedures and objectives. This learning model was developed on the learning trend in which students became active and creative. The role of lecturers as facilitators and inspirations, was challenged to be able to apply the principle of flexibility, to have thorough and detailed preparation, to be able to generate multi-interactions, more intensive exercises and assignments, to have various learning resources and to use tools. This learning trend has shown that the educators were not the authorities who have the right to intimidate students in learning. But educators appeared as directors, scenario compilers, actors and controllers of learning that were reliable, referring to the achievement of competence of students according to subjects and fulfilling the vision and mission of the university where they taught [8].

Through this CIA approach, the lecturers at Sawerigading University were finally challenged to be able to make maximum use of online applications, for example through the zoom application not only through face-to-face methods but also being able to apply various learning models such as small group discussions, quizzes, flash cards, punctums, puzzles, mind maps, market places, as well as various creative, innovative and active (CIA) methods.

\section{Methodology}

The research method used in this research was descriptive qualitative research method to determine the attitudes, behavior, perceptions, and experiences of students in implementing the CIA learning approach. The sample used was 102 students from various disciplines at Sawerigading University Makassar who were randomly selected. The data collection techniques used were questionnaires and observations. The data obtained from the results of the questionnaire distributed to the sample of the study were then systematically processed to be presented as research results.

In its implementation, the questionnaires were distributed twice, in July 2020 when the online learning process had been going on for 3 months, but the lecturers had not been equipped with a CIA learning approach. The questionnaire distribution stage was then carried out in the second session, in the last week of October 2020. In this second session, the lecturers had first attended online learning system training on the application of the CIA learning approach. The questions in the questionnaire distributed in the second stage were the same as those in the first stage which consist of 10 questions. The responses from the two stages of distributing the questionnaire were then compared each other to elaborate on the effectiveness of implementing the CIA learning approach. The questionnaire was distributed to students via google form. 


\section{Result and Discussion}

As previously explained that the data obtained from the distribution of questionnaires before and after the lecturers attended the CIA learning approach training and applied it in the online learning system were then compared with each other and described in detail to see the effectiveness of using the CIA learning approach in various interesting activities through the online learning system. The data obtained from the results of online questionnaires are as follows:

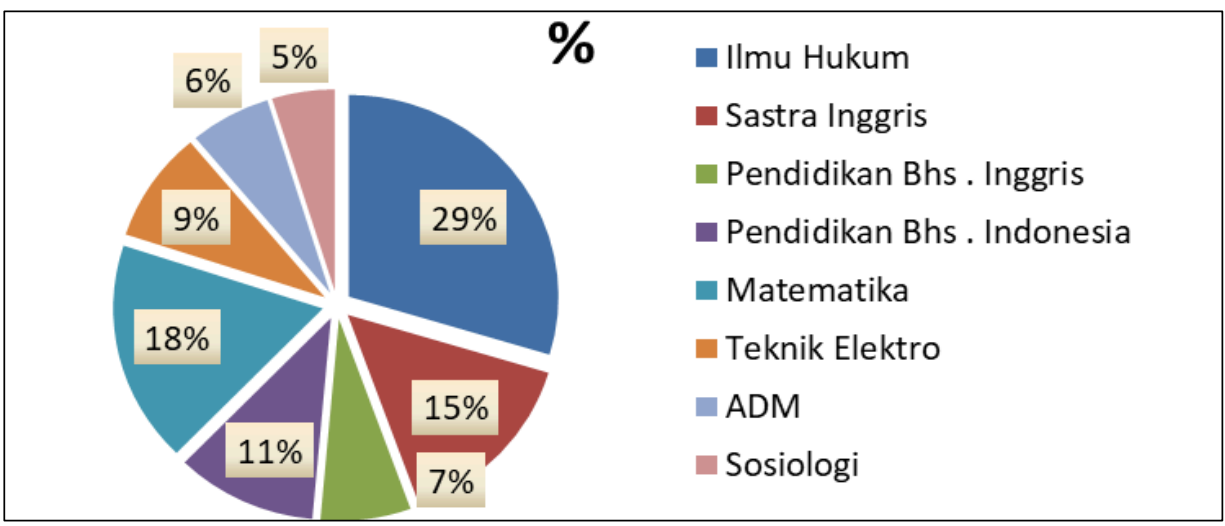

Fig. 1. Percentage of Number of Students from Each Study Program

The number of samples in this study were 102 students who were students at Sawerigading University Makassar from 8 different study programs and they were selected randomly.

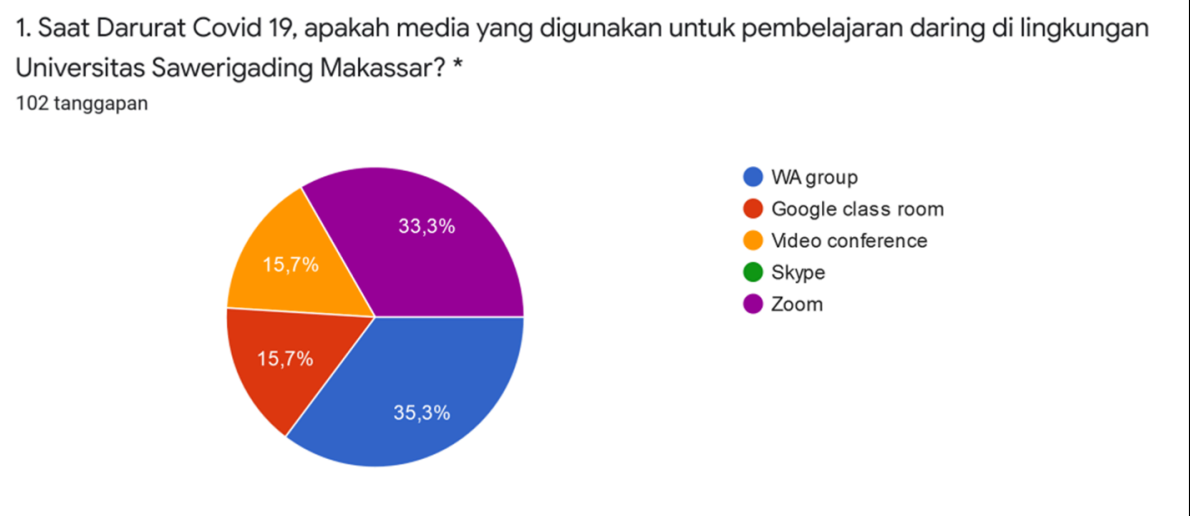

Fig. 2. Learning media for the period of May-July 2020 
1. Saat Darurat Covid 19, apakah media yang digunakan untuk pembelajaran daring di lingkungan Universitas Sawerigading Makassar? *

102 tanggapan

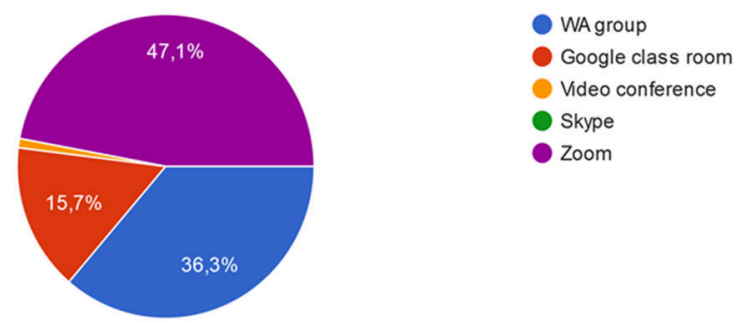

Fig. 3. Learning media for the period of August-October 2020

Before participating in the training of using the CIA learning approach, $35.3 \%$ of the lecturers at Universtas Sawerigading Makassar tended to use the WA Group application, while the remaining $33.3 \%$ used the zoom application. After taking the CIA learning approach training, and applying it to the online learning system, the lecturers switched to use the zoom application. This can be seen from the results of the questionnaire period 2 (August-October). Zoom app users increased from $33.3 \%$ to $47.1 \%$. This was supported by the features in the zoom application which were much more diverse so that in one meeting the lecturers could process the class through various new methods that they have obtained in the CIA learning approach training.

2. Saat darurat Covid19, apakah seluruh kegiatan pembelajaran terlaksana dengan baik (terstruktur, sesuai jadwal, terkoordinasi)? 102 tanggapan

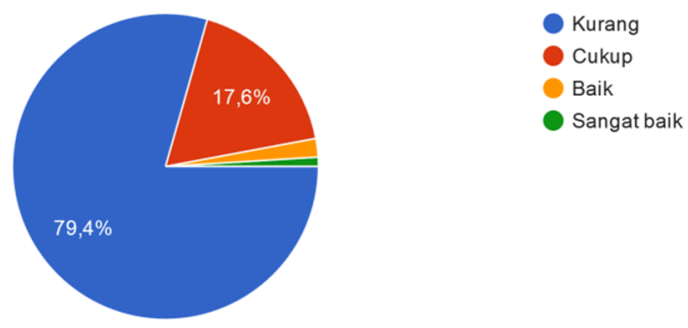

Fig. 4. The Implementation of learning for the period May-July 2020 
2. Saat darurat Covid19, apakah seluruh kegiatan pembelajaran terlaksana dengan baik (terstruktur, sesuai jadwal, terkoordinasi)?

102 tanggapan
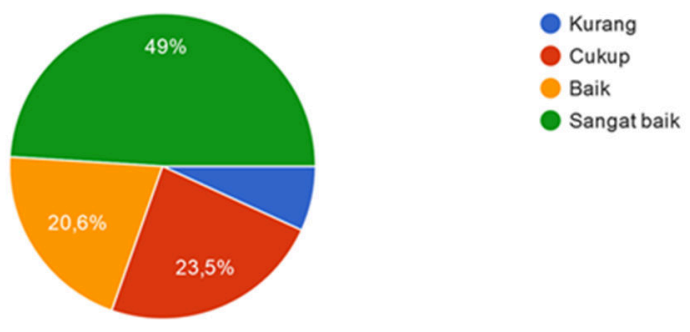

Fig. 5. The Implementation of learning for the periode of Aug-Oct 2020

The second question in the questionnaire is whether the implementation of learning activities could be structured and coordinated or not. The results shown were that in the first 3 months of implementing the online learning system, $79.4 \%$ of respondents agreed that the running system was less structured and coordinated. However, in the 3 to 6 month period running, online learning activities have been very good. This could be seen from the response of $49 \%$ of respondents agreed that the application of the online learning system could be carried out well, structured and coordinated.

The coordination of the online learning system in the second period was inseparable from the willingness of the Sawerigading Makassar University lecturers to follow the instructions they received in the CIA training regarding the preparation of lesson plans in every meeting. So in approximately 100 minutes of presentation (face to face online) for 2 credits of courses and additional 50 minutes for projects or assignments for courses with a load of 3 credits, each lecturer got instructions on dividing 100 minutes of time into various activities, for example : 5-15 minutes of warming up and ice breaker activities. Greetings, simple quizzes related to the previous material with the aim of reviewing the previous material as well as breaking the rigidity of the online classroom atmosphere was an important step to attract students' attention so that they could join the online classes and felt enthusiastic and challenged from the first minute.

The next step or activity was lead in. In the lead-in activity, the lecturer had about 5-15 minutes to lead or direct students to the main material that would be discussed on that day but not directly. It took a variety of creative activities in this lead-in stage by using experiential learning where the students were stimulated to find and to discuss daily problems related to topics that would be presented by the lecturers.

The third step was a presentation where the lecturers had the opportunity not more than 30 minutes to present the material for the day. In these 30 minutes, the lecturer spent 30 minutes speaking (teacher center) and clarified the students' basic understanding of the material they have presented in the lead in stage.

The fourth step was learning activity / project. In this stage, the zoom situation which was initially calm for 30 minutes before would turn into an interactive online class because the lecturer would again direct the students to be active in various activities such as group discussions in smaller zoom groups, pairing discussions, poster comments, mind maps, project based learning, talk shows, role play, debating, think pair share, two stay two stray, 6 thinking 
hats, philosopher's walk, card short, punctum, and various creative, innovative, creative activities or learning projects, and attractive (CIA).

The last step was concept checking. Before ending the online class, the lecturers were required to do concept checking or check students' understanding of the material provided based on wh-questions (What, where, when, why, who). By applying these 5 stages, the rigid and monotonous teaching process online could be resolved as soon as possible in the 2nd period from August to October 2020.

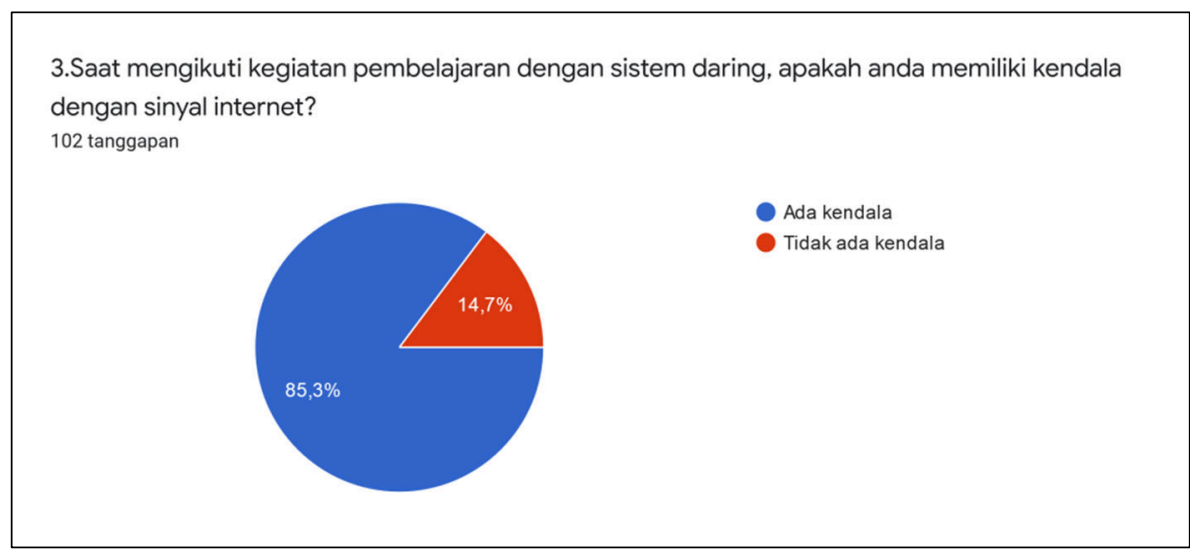

Fig. 6. The Obstacles in implementing the learning period of May-July 2020

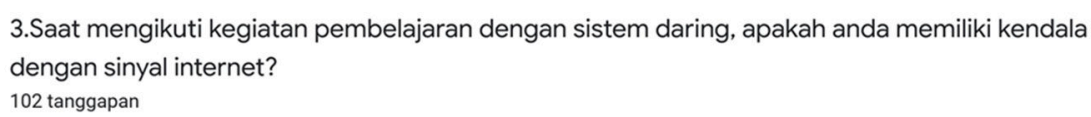
102 tanggapan

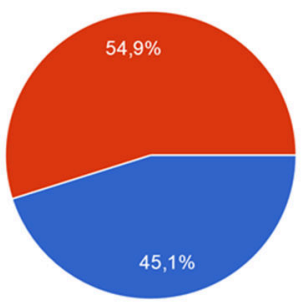

Ada kendala

Tidak ada kendala

Fig. 7. The Obstacles in implementing the learning period of Aug-Oct 2020

Based on the data from diagrams $3 a$ and $3 b$, it can be seen that there is a significant decrease in the constraints experienced by both lecturers and students in implementing online learning. In the first period, $85.3 \%$ of students said that they experienced problems in the online learning system, while in the second period, the number fell to $54.9 \%$.

From the results of the interaction through the WhatsApp application of each study program, it is known that most of the obstacles faced by students were the limited quota they had, the unstable internet network around their residence, especially for students who were forced to return home. Another obstacle wasthat they were not familiar with the use of the zoom application, google classroom, google meet, and other online applications. Luckily this 
did not take place continuously where the conditions were starting to improve. This was related to the elimination of PSBB, the assistance of free internet quota from the government to lecturers and students, the number of online seminars, as well as tutorials on how to use various online applications on YouTube so that both lecturers and students could learn how to use the application online.

The government and universities also provided COVID 19 scholarship assistance to the students to ease the burden on parents who had to be sent home during the first 3 months of the pandemic. These various efforts have made the obstacles faced in the first quarter drastically reduced in the second quarter.

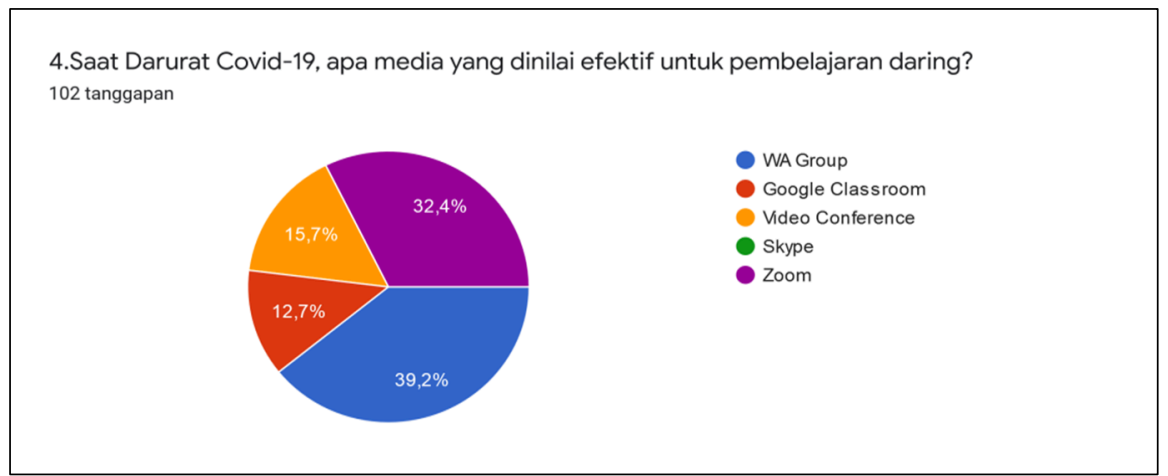

Fig. 8. The Effective media in online learning for the period of May-July 2020

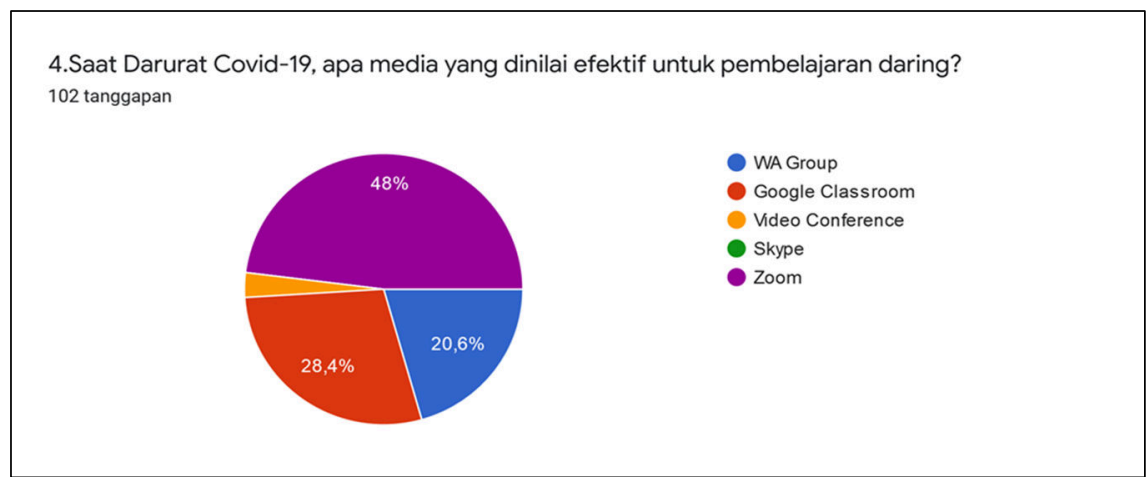

Fig. 9. The Effective media in online learning for the period of Aug-Oct 2020

After participating in the CIA learning approach training, there was a shift towards the position of the media which was considered the most effective for use in the online learning system. In the first period, the wa group application was the most dominant application used, which was $39.2 \%$, while the second position was occupied by the zoom application at $32.4 \%$. In the second period, there was a shift in position where the most dominant application used was the $48 \%$ zoom application while the wa group application was $20.6 \%$.

In the first period, the wa group application was the most dominant because among all applications, wa group was an application that was familiar to students, while the zoom application was still struggling with various difficulties understanding each feature so that the lecturers only understand the application to give lectures in face to face without distraction, models and learning activities that were more creative, innovative and active, for example how 
to display videos, how to share presentation slides, how to divide large groups in the zoom application into small groups but the lecturers could still enter each small group for monitoring, sharing interesting quizzes, and other methods in the zoom application. Luckily after participating in the CIA learning approach training, the lecturers have become very creative in presenting an online learning system so that they could improvise in giving courses through the zoom application which has more creative features than the wa group application used previously.

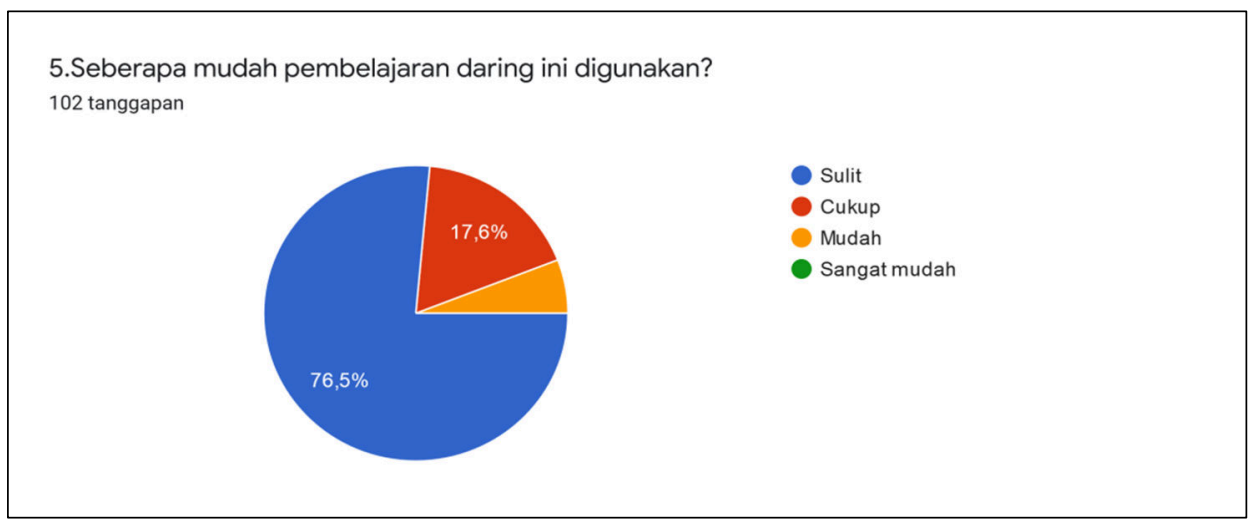

Fig. 10. The Ease of online learning for the period of May-July 2020
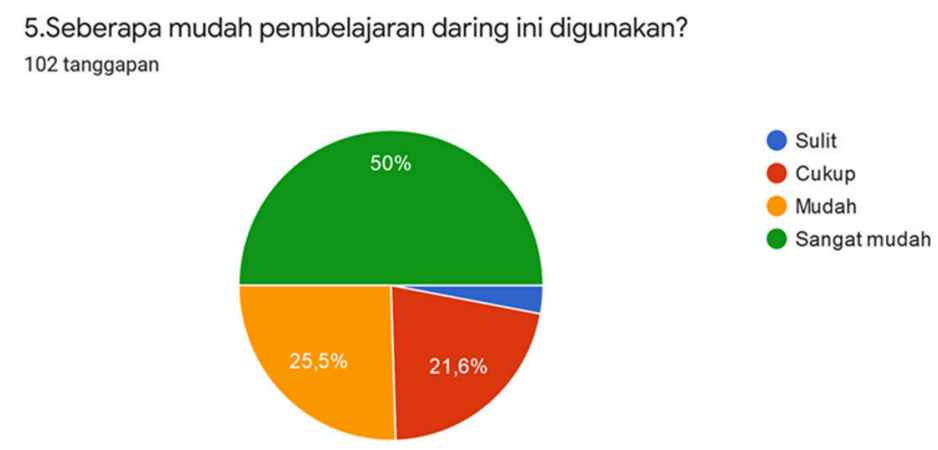

Fig. 11. The Ease of online learning for the period of Aug-Oct 2020

In the beginning the university implemented an online lecture system, not only lecturers who found it was difficult to apply the online lecture system. Students as well, because of the PSBB policy had to return to their hometowns had also encounter very high difficulties when suddenly they had to be forced to use various applications that they did not know before with various technical problems related to quotas and the stability of the internet network in their hometowns.

As many as $76.5 \%$ of students found difficulties in the first period of implementing the online learning system. However, in the second period, this number dropped drastically so that $50 \%$ of students finally agreed that during the period of August - October 2020, they had 
mastered the applications used and thought that the online learning system was very easy, effective, and efficient.

6.Bagaimanakah interaksi dosen dan mahasiswa menggunakan sistem daring?

102 tanggapan
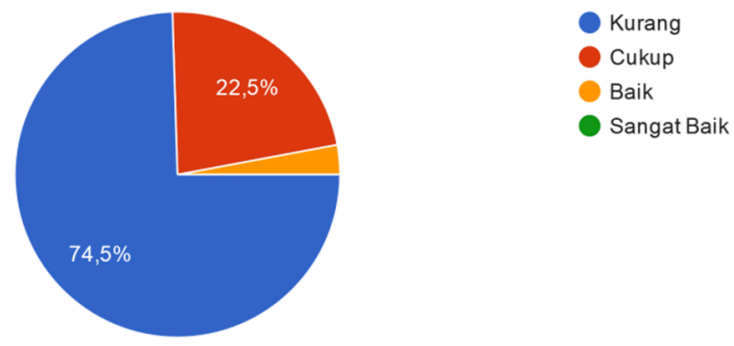

Fig. 12. The Interactions among lecturers and student for the period of May-July 2020

6.Bagaimanakah interaksi dosen dan mahasiswa menggunakan sistem daring? 102 tanggapan
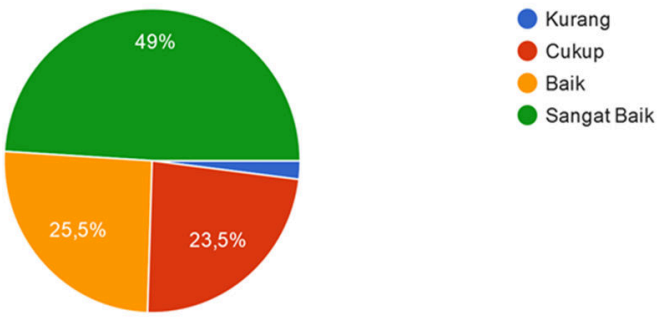

Fig. 13. The Interactions among lecturers and student for the period of Aug-Oct 2020

It was no less important to be an evaluation material for LPM at Sawerigading University Makassar during the implementation of the online learning system to evaluate the interaction among lecturers and students. This was deemed very necessary to maintain the quality, to monitor and to evaluate the system that has been running so that the quality of learning was maintained during the pandemic period even though the lecturers and students did not meet face to face directly. The results obtained were $74.5 \%$ of students thought that the interaction among them and the lecturers was very lacking. Less in this case meant passive where they were more likely to be listeners, and lecturers were the only speakers when the face-to-face online system was implemented in the first stage.

In the second stage, the situation was much more controlled when various interesting methods were applied by the lecturers through the zoom application. For example the use of flashcard techniques, small group discussions, and various forms of interesting online quizzes so that the students could actively contribute, provide their responses, ideas, and answers. This 
situation had succeeded in changing the atmosphere of online classrooms to become less monotonous but more attractive.

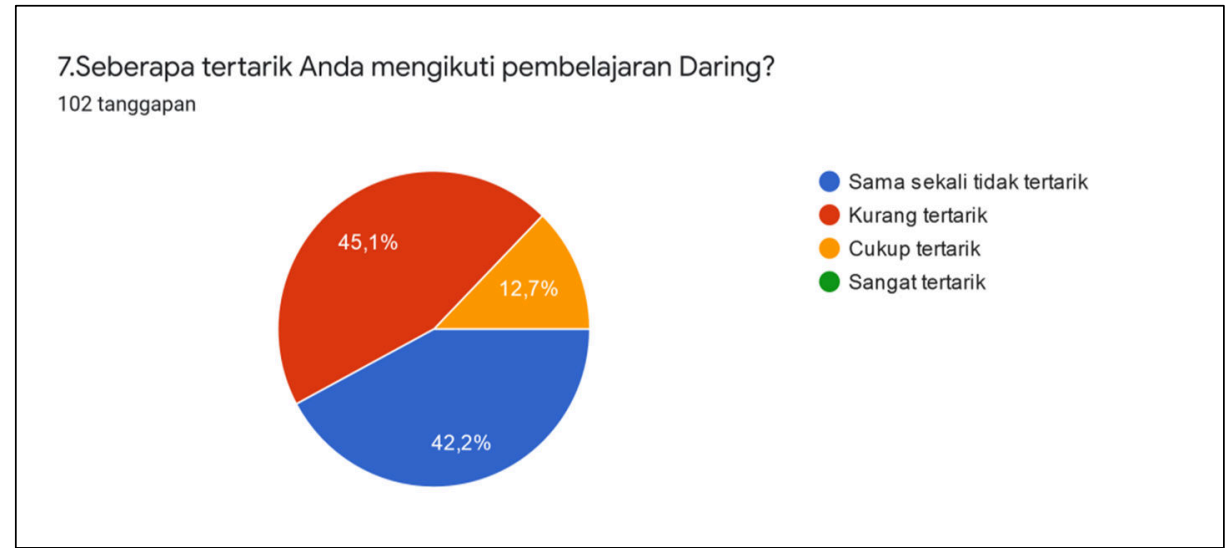

Fig. 14. The Interest in participating in online learning for the period of May-July 2020

7.Seberapa tertarik Anda mengikuti pembelajaran Daring? 102 tanggapan

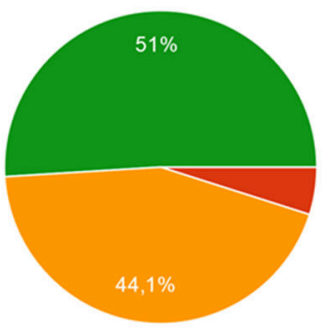

Sama sekali tidak tertarik

Kurang tertarik

Cukup tertarik

Sangat tertarik

Fig. 15. The Interest in participating in online learning for the period of Aug - Oct 2020

In the first period, the vice rector I, academic bureaus, and LPM received a lot of complaints from lecturers, including the low number of students joining online classes, or when students joined but installed a virtual background and when the lecturer called them there was absolutely no responses from the students. This shown the low interest of students in taking online lectures. About $45.1 \%$ stated that they were less interested and $42.2 \%$ stated that they were not at all interested in this system and preferred the offline system due to the boredom and monotonous of the online lecture process. However, in the second period, this opinion changed when $51 \%$ of students finally changed their views and argued that the online system made them very interested in attending lectures because of the many interesting activities that for them were very challenging and made students curious. 
8.Apakah pembelajaran daring yang sudah dilakukan bersifat kreatif, inovatif dan aktif?

102 tanggapan

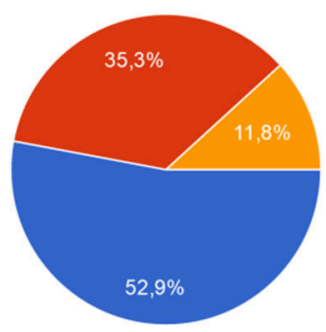

Tidak

Kurang

Cukup

Sangat kreatif, inovatif dan aktif

Fig. 16. The effectiveness of online learning for the period of May-July 2020

8.Apakah pembelajaran daring yang sudah dilakukan bersifat kreatif, inovatif dan aktif? 102 tanggapan

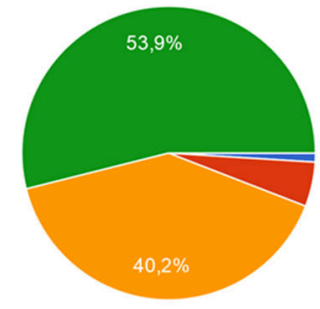

Cukup

Sangat kreatif, inovatif dan aktif

Fig. 17. The effectiveness of online learning for the period of Aug - Oct 2020

It were about $52.9 \%$ of students considered that online learning was ineffective and $35.3 \%$ of students considered the online learning system was less ineffective. However, in the second period, as many as $53.9 \%$ of the total respondents agreed that the online learning system in the second stage was very creative, innovative, and active which was supported by the preparation of detailed, organized lesson plans, which were monitored and evaluated periodically by the university and LPM unit or the quality control unit of each study program. 
9.Apa model pembelajaran sistem daring yang digunakan oleh dosen - dosen di Universitas Sawerigading Makassar?

102 tanggapan

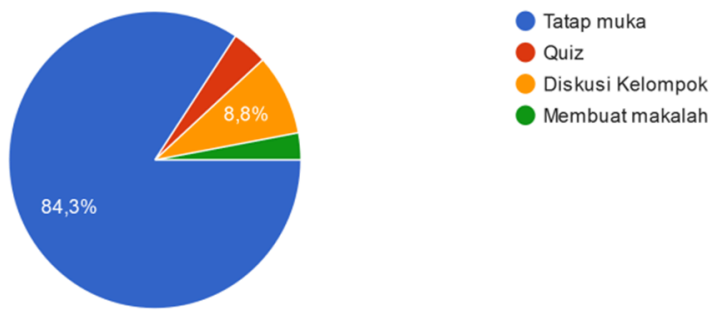

Fig. 18. Online learning model for the period of May-July 2020

9.Apa model pembelajaran sistem daring yang digunakan oleh dosen - dosen di Universitas Sawerigading Makassar?

102 tanggapan
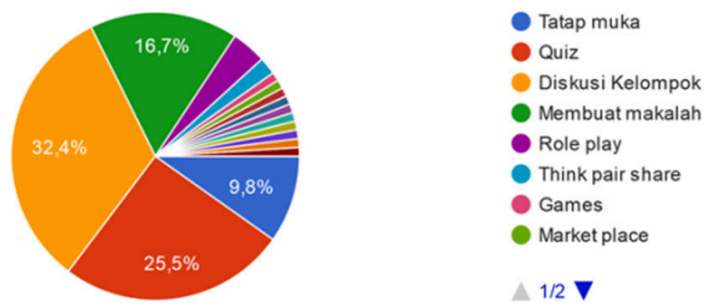

Fig. 19. Online learning model for the period of Aug - Oct 2020

In the first three month period, May - July 2020, $84.3 \%$ of students as respondents stated that the learning model used by lecturers - lecturers was an online face-to-face learning system, followed by paper making activities, quizzes, and big group discussions. This became less effective because only a few active students played a prominent role, while students who were classified as passive would remain silent, became listeners, and felt bored with monotonous online lecturer activities. It was worth appreciating the hard work of the lecturers and LPM because in the following three months this situation was under control. The results could be seen from the diagram 9b where there were various models of chasing activities, including group discussions, quizzes, writing papers, role play, games, market place, think pairs share, as well as various other creative activities. 
10.Bagaimana tanggapan anda terhadap model pembelajaran sistem daring yang digunakan oleh dosen - dosen di Universitas Sawerigading Makassar?

102 tanggapan

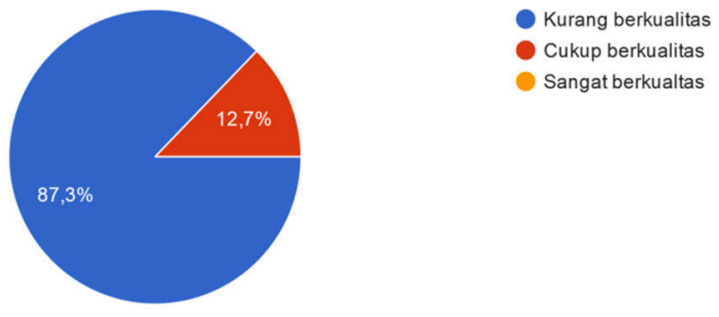

Fig. 20. Responses to online learning for the period of May-July 2020

10.Bagaimana tanggapan anda terhadap model pembelajaran sistem daring yang digunakan oleh dosen - dosen di Universitas Sawerigading Makassar?

102 tanggapan

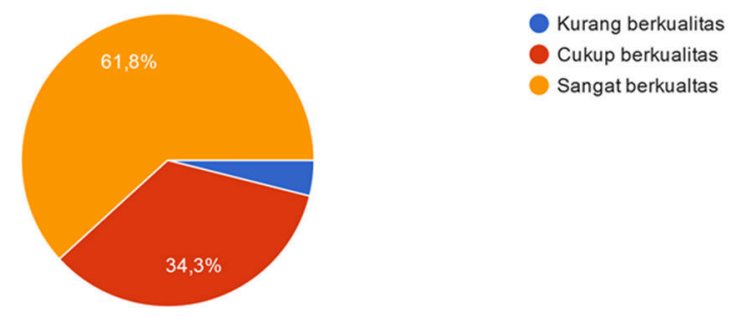

Fig. 21. Responses to online learning for the period of Aug - Oct 2020

The latest information obtained from distributing the online questionnaires via google form was about how students responded to the online system learning model applied by lecturers at Sawerigading University during the first three months of the pandemic. The results obtained were $87.3 \%$ of students stated that the activity was poor. The consequences included the minimal presence of students in participating in virtual learning, students who took part in the learning process felt a very high level of boredom, they became very passive, the level of understanding of the material provided by the lecturer was lack, the lack of student activeness in submitting assignments given by the lecturer, and the most dominant thing seen was that the students preferred to put a virtual background on their zoom screen.

Monitoring and evaluation efforts that continued to be carried out by the LPM of Sawerigading University in response to complaints from various parties, students and lecturers had finally been able to produce tangible results. As seen from the results of the two-hold questionnaire for the period August - October 2020 where by applying the CIA learning approach in which there were various interesting, creative, innovative, and active activities presented in the form of clear and detailed lesson plans that were able to make $61.8 \%$ of respondents agreed that in the 2 nd period of this pandemic, the online learning system at 
Sawerigading University Makassar was of high quality, 34, 3\% stated that they were of sufficient quality and only less than $1 \%$ of respondents stated that they were not qualified.

\section{Conclusion}

In general, the results showed that students' interest in online learning systems increased from $12.7 \%$ which stated that the learning system applied by lecturers during the first three month of the pandemic period was less qualified to $61.8 \%$ of high quality in the second quarter so that students felt very interested in following the online learning system. The students; response agreed that the online learning system by Sawerigading University lecturers was more creative, interactive and active after the CIA learning approach was applied through various activities in the virtual room. These results identified that the students gave positive responses to the application of the CIA learning approach as an effort by the University of Sawerigading Makassar to find a solution to the problem of low student enthusiasm for faceto-face learning methods online in a virtual room that previously seemed monotonous and less attractive.

\section{References}

[1] Surat Edaran Kementerian Pendidikan dan Kebudayaan (Kemendikbud) Nomor 15 Tahun 2020 tentang Pedoman Penyelenggaraan Belajar Dari Rumah Dalam Masa Darurat Penyebaran Covid-19 (Ministry of Education and Culture (Kemendikbud) Circular Letter Number 15 of 2020 concerning Guidelines for Organizing Learning from Home in an Emergency for the Spread of Covid-19).

[2] Surat Edaran Mendikbud Nomor 4 Tahun 2020 tentang Pelaksanaan Pendidikan Dalam Masa Darurat Coronavirus Disease (Covid-19) .(Minister of Education and Culture Circular Number 4 of 2020 concerning Implementation of Education in an Emergency for Coronavirus Disease (Covid-19)

[3] Kuntarto, E. 2017. Keefektifan Model Pembelajaran Daring dalam Perkuliahan Bahasa Indonesia di Perguruan Tinggi (The Effectiveness of Online Learning Models in Indonesian Language Lectures in Higher Education). Indonesian Language Education andLiterature,3(1), 99-110.10.24235/ileal.v3i1.1820

[4] Gikas \& Grant. 2013. Mobile Computing Devices in Higher Education: Student Perspectives on Learning with Cellphones, Smartphones \& Social Media. The Internet and Higher Education 19:18-26 DOI: 10.1016/j.iheduc.2013.06.002

[5] Darmalaksana, Wahyudin, dkk. 2020. Analisis Pembelajaran Online Masa WFH Pandemic Covid-19sebagai Tantangan Pemimpin Digital Abad 21 (Analysis of Online Learning during the WFH Pandemic Covid-19 as a Challenge for 21st Century Digital Leaders). Karya Tulis Ilmiah (KTI) Masa Work From Home (WFH) Covid-19 UIN Sunan Gunung Djati Bandung.

[6] He, W., Xu, G., \& Kruck, S. 2014. Online IS Education for the 21st Century . Journal of Information Systems Education.

[7] Argaheni, Niken Bayu. 2020. Daring Saat Pandemi COVID-19 Terhadap Mahasiswa Indonesia (Online During the COVID-19 Pandemic Against Indonesian Students) PLACENTUM: Jurnal Ilmiah Kesehatan dan Aplikasinya. Vol 8, No 2 (2020) > Argaheni 
[8] Mawardi B, Pitalis. 2015. Penerapan Model Pembelajaran Aktif Kreatif Dan Menyenangkan (Paikem) Terhadap Hasil Belajar Mahasiswa Pendidikan Geografi Ikip Pgri Pontianak (Application of Creative and Fun Active Learning Model (Paikem) on Learning Outcomes of Geography Education Students of Ikip Pgri Pontianak), SOSIAL HORIZON: Jurnal Pendidikan Sosial Vol. 2, No. 1, Juni 201547 